\title{
Female Masculinity and Power Relation in Patriarchic System: Case Study Tomboyism of Bacha Posh in Afghanistan
}

\author{
Made Fitri Maya Padmi \\ International Relations Department, Universitas 17 Agustus 1945 Jakarta - Indonesia \\ Email: fitrimayapadmi02@gmail.com \\ Submitted: 23 Maret 2018, Accepted: 17 Mei 2018
}

\begin{abstract}
The biological/essentialist theory of gender assumes that biological sexes determine the behavior patterns and roles of males and associates them with masculinity and females and associates them with femininity. However, there is debate to determine whether genders are biological or socially and culturally constructed. Feminist critique of the power relation between masculinity and femininity defined as the power to give privilege to the position of masculinity and men, and acknowledge the subordination of femininity and women. People also guided to conform to gender norms in society as identity. Female masculinity emerged as part of a resistance to the gender norms where females should adopt and perform feminine values and ways of life. This paper analyze the position of female masculinity, which is distinct from masculinity in patriarchic systems. This paper also analyze the early stage of female masculinity, tomboyism called Bacha Posh as experienced by many girls in Afghanistan. This paper showed to us that the phenomena of Bacha Posh reflect the gender trait was not flexible. It was decided by the need to fulfill patriarchy system in Afghan society.
\end{abstract}

Keywords: Gender Relations, Female, Masculinity, Bacha Posh, Patriarchy, Tomboyisme.

\begin{abstract}
Abstrak
Konsepsi biologis/esensialis mengenai gender menyatakan bahwa jenis kelamin biologis manusia menentukan pola perilaku manusia, dan peran laki-laki yang dikaitkan dengan maskulinitas dan perempuan dengan femininitas. Akan tetapi, terdapat perdebatan mengenai apakah gender adalah sesuatu yang berkaitan dengan aspek biologis manusia atau merupakan hasil dari konstruksi sosial budaya. Kritik dari kaum feminis mengenai hubungan kekuasaan antara maskulinitas dan femininitas adalah dominasi hak khusus bagi kaum laki-laki dan sifat maskulin, dan pengakuan atas posisi perempuan dan sifat feminin yang lebih rendah dari laki-laki. Perempuan dengan sifat maskulin atau female masculinity dilihat sebagai bentuk perlawanan terhadap norma gender yang ada di masyarakat dimana perempuan harus mengadopsi dan bersikap berdasarkan sifat-sifat feminin sebagai jalan hidu Tulisan ini bermaksud menganalisis posisi perempuan yang bersifat maskulin atau yang biasa disebut female masculinity yang dibedakan dari bentuk maskulinitas lainnya dalam sistem patriarki. Tulisan ini juga menganalisis tahap awal dari female masculinity yakni tomboyisme yang dialami oleh anak-anak perempuan di Afghanistan yang disebut Bacha Posh. Fenomena ini mengindikasikan kekuasaan yang dimiliki sifat maskulin dalam membentuk identitas gender di masyarakat, dimana female masculinity diposisikan di luar dari sistem maskulinitas dalam hal kekuasaan, legitimasi dan peran dalam masyarakat.
\end{abstract}

Kata Kunci: Relasi Gender, Female, Masculinity, Bacha Posh, Patriarchy, Tomboyisme.

\section{INTRODUCTION}

Traditional conceptions of gender assumed that gender attached to the biological aspect of humans.

The biological/essentialist theory of 
gender assumes that biological sexes determine the behavior patterns and roles of males and associates them with masculinity and females and associates them with femininity (Diamond, 2000). Conversely, social constructionists argued that gender is a process of identity construction related to how people experience gender within social interactions. Gender performances are greater than just the biological bodies of humans, which presume males can perform in feminine ways and females can perform in masculine ways.

Female masculinity is a result of gender performativity. It also challenges the dichotomy of gender and sex representations in society. Masculinity often considered as an actions that stereotypically related to men or boys. However, the existence of female masculinity brought new perspectives that masculinity performed by the outside of the male body. There has been a debate regarding whether female masculinity is part of masculinities (e.g. masculinities within race, economic status, heterosexuality and homosexuality), whether it is another form of femininity, or is a third gender category in a patriarchic social system.

The term "masculinities" represents the power, legitimacy and privilege that constructed in society. This paper will analyze the position of female masculinity, which is distinct from masculinity in patriarchic systems. Although the gender performance of female masculinity tends to have more masculine values than feminine values, females exhibiting these traits do not have privilege or power in patriarchic society and viewed differently from traditional forms of masculinity. This paper will also analyze the early stage of female masculinity, tomboyism called Bacha Posh as experienced by many girls in Afghanistan. This form of tomboyism created by a society where the girls told to dress and act as boys. The society and family constructed masculine identity and performativity with these girls, but when they enter puberty, social pressure will push them to transform 
into feminine girls. This phenomenon suggests that masculinity possesses power in society and shapes gender identity, while female masculinity placed outside the masculine world in terms of power, legitimacy and privilege in society (Claire \& Alderson, 2013; Nordberg, 2010).

\section{Female Masculinity Construction}

Traditional views of masculinity construction narrowed into sex roles and the male body, particularly as related to the aesthetic appearance of muscular body shape and functional aspect of strength, endurance and capability (Wickman, 2010). However, masculinity itself constructed in everyday life and within economic and institutional structures where different types of masculinities are produced (Connell, 2005). Different social conditions construct different types of masculinities, such as the aggressive masculinity commonly seen in military institutions, masculinity in sports, economic-based or working-class masculinity, racial masculinity, and homosexual masculinity. It is essential to recognize that perceptions of gender and masculinities are not fixed, thus it is not suitable to limit them by identifying their existence to the biological bodies of males only. Judith Butler (1990) made an important statement as a strong basis for contemporary gender perception in which gender and even the sexes constructed through the cultural means and culturally unmediated bodies. The construction of masculinities from a social aspect captures different essences of masculinities. The conceptions of masculinities include activeness, risktaking, responsibility, irresponsibility, aggression, protection, and social reproduction (Connell, 2005).

The gender binary between masculinity and femininity is inherently relational; as Connell stated, "Masculinity does not exist except in contrast with femininity" (Connell, 2005, 68). Connell analyzed masculinity and found it to be the polar opposite of femininity. The dichotomy of masculine and feminine are related to the use of language, 
where language not only creates opposite definitions for each notion, but also puts value into them (Butler, 1990; Hooper, 2001). Some opposite pairs that can describe the relation between masculine and feminine are hard/soft, rational/irrational, active/passive, dominant/submissive, competitive/caring, public/private, aggressor/victim, war/peace, and self/other (Hooper, 2001).

When it is said that gender is culturally constructed, it can be defined according to different culture norms and thus may result in different types of gender formations. According to Foucault, language has the power to shape gender identity and its position as a cultural norm (Buttler, 1990). The continuity of language usages constructs the normalization of language as a fix notion. Language also constitutes a power relation within the gender binary that seems to be asymmetrical. Feminist critique of the power relation between masculinity and femininity defined as the power to give privilege to the position of masculinity and men, and acknowledge the subordination of femininity and women (Hooper, 2001). The power structure, which privileges the position, function, and role of men in society recognized as a patriarchic system. Edley and Wetherell (1996) explained how men have dominated women with the power embedded within them through the patriarchic system:

"Men have dominated over women, by and large, because they have manage to gain a stranglebold on meaning. What it means to be a man, what it means to be a woman; what jobs constitute men's work. and what jobs constitute women's work. It is through the ability to control the ways in which society thinks about these things that have provided men with the basis of their power" (Wetherell, 1996, 107).

The language of gender dichotomy attempts to normalize the reality by establishing gender segregation, imposing stereotypes and overshadowing the complexity of social phenomena. People guided to conform to gender norms in society as identity. Female masculinity and male femininity emerge as phenomena of gender complexity in social life. Female masculinity seen as part of a 
resistance to the gender norms where females should adopt and perform feminine values and ways of life. Halberstam stated in her book Female Masculinity that "female masculinity has been situated as the place where patriarchy goes to work on the female psyche and reproduce misogyny within femaleness" (Hallberstam, 1998, 9).

Female masculinity emerges as a challenge to gender dichotomy and the statement of gender as cultural dynamic that can be taken on and off (Nguyen, 2008). Some of female masculinities take different forms and are known in society as 'tomboy', 'butch', 'drag king', 'dykes', and so on (Halberstam, 1998; Nguyen, 2008). The gender performativity brought by female masculinity is how masculine behaviors and roles embodied inside femininity and within the female body. Nguyen (2008) focused on the butch performativity, in which butch lesbians perform masculinity in both appearance and in terms of actions that were like men, dress like men and hide or minimize the feminine aspect of the female body (butches prefer sports bras or 'strap' their breasts, rather than wear push-up bras); and functionally, in terms of how things operate within masculine values.

Female masculinity appears to be the combination of social resistance and articulation of male masculinity in term of supremacy (Halberstam, 1998). Female masculinity seems to defy the power embedded in patriarchy, but also implements it in actions regarding other women. Those who exhibit female masculinity accused of rejecting or denying the female role and femininity, and treat women as men do in patriarchic system (Nguyen, 2008). Women's liberation movements, which were instigated by the feminists, criticized the adoption of patriarchic, masculine behaviors and roles that served to dominate women's positions in social life (Gardiner, 2002). Counter arguments from the female masculinity point of view suggest that they place themselves in antagonistic relation to patriarchy, challenge the privilege of masculinity; they are not simply imitating masculinity, but 
challenge it to be perform and mobilized through the female body (Nguyen, 2008; Wiegman, 2002). It means that by putting themselves in antagonistic positions to masculinity and patriarchy, female masculinity is distinctive to the notion of masculinity.

It said that female masculinity emerged to challenge the patriarchic system; however, their position within society gender norms is still questioned and sometimes unrecognized. Haberstam (1998) stated that female masculinity is a form of 'maladjustment' and 'misidentification' of gender norms in society. When masculinity is reflecting power and privilege over the social life position, it appears that power and privilege are out of reach for female masculinity to achieve. Female masculinity excluded from the power relation within the category of masculinity. The notion of 'maladjustment' is similar to the language of exclusion; it is not unusual to define masculinity as "Self" and female masculinity as "Other". Female masculinity often performed out of defensiveness by women who have experienced structural violence in patriarchic system and defensiveness about being lesbian in heteronormative society (Nguyen, 2008). There are attempts to naturalize female masculinity or butch as a third gender category, as in transgender or transsexual identifications that are apart from masculine and feminine genders (Halberstam, 2012; Wickman, 2010). Female masculinity considered as an "independent gender - a gender that is often unrecognized, discredited, and disregarded" (Levitt and Hiestand, 2004, 612).

\section{Tomboyism}

Tomboyism is a term that used to describe early stages of female masculinity in childhood periods. Tomboyism commonly appears in the experiences of girls. A notion of the tomboy refers to a girl who behaves and dresses like a boy and has been distinguished from non-tomboy girls (Claire \& Alderson, 2013). Tomboy girls tend to have male-typical interests 
such as sports, aversion to female clothes, male mannerisms, male-type activity preferences, and boyish appearances (Bailey, Bechtold, \& Berenbaum, 2002). To a certain degree, society views tomboy behavior in girls as part of childhood behavior that more tolerated than girl behavior by boys (Halberstam, 1998). Tomboyism also reflects the desire of freedom enjoyed by boys.

Childhood is a period when a person is learning about the gender and sexual preference that apply in society. Gender development often begins from the pregnancy period of a mother. Parents tend to start making arrangements by preparing names, toys, and nursery equipment that aids in assigning gender identity right after they know the biological sex of their baby (Dragowski, Scharron-Del Rio, \& Sandigorsky, 2011). Gender socialization in early childhood based on gender norms and stereotypes, which intertwined with cultural, ethnic, and religious values in society. Children start learning the gender norms of masculine and feminine from their parents, family, school, and surrounding environment. Children taught to understand that gender connected to physical and behavioral characteristics that also construct different responsibilities that attach to it (Diamond, 2000; Dragowski, Scharron-Del Rio, \& Sandigorsky, 2011).

Gender identity formation built upon the integration of complex biological, psychological processes and expressed through the societal values (Diamond, 2000; Gender Identity Research and Education Society, 2006). Tomboy girls experience different gender socialization and treatment from parents and family that may lead to "sex-atypical behaviors" (Bailey, Bechtold, \& Berenbaum, 2002, 334). Different sex or gender socialization and treatment received by girls may significantly affect their behavioral differences. Such socialization commonly appears in strong patriarchic societies where boys are preferred rather than girls, or where families sometimes treat their daughter as a son. 
Societal tolerance toward tomboyism is typically limited to the time of puberty (Halberstam, 1998). Tomboyism is seen as natural phase when it occurs as part of exploration toward sex and gender differences because in certain conditions tomboy girls still behave like typical girls and in feminine ways (Bailey, Bechtold, \& Berenbaum, 2002; Halberstam, 1998). Research related to tomboyism reflected that tomboy girls give up their non-conforming identity when they reach puberty or the transition to adolescence phase (Carr, 2007; Claire and Alderson, 2013). The research also indicated that most of the reasons why girls stop being tomboys is due to social pressure from parents or family, social pressure from friends, desire to attract boys, and physical developments (e.g. menstruation, growing breasts and hips) (Claire and Alderson, 2013).

Social pressures seem to be the significant reasons for tomboy girls to re-conform with femininity and a female gender identity. Halberstam (1998) stated that tomboyism "punished" if shown in extreme values of masculinity and extends beyond childhood into adolescence. In the patriarchic society, where being a man is a privilege, adolescence is a symbol of freedom and power for boys, while it becomes a symbol of oppression and restriction for tomboy girls as they once experienced freedom and selfdetermination during their childhood. For some, become a feminine girl or re-conforming to femininity means restraining their bodies, behaviors, and functions in social life. A society that attempts to maintain gender norms for all members of society often does not accept or tolerate as maladjustment of gender identity (Claire \& Alderson, 2013). The conformity to the expectation of gender norms is also part of gaining social acceptance and acknowledgement. Having social pressure might bring the psychological experience of rejection; thus obeying gender norms in the society expected to bring self-redemption and reinstatement in social life. 
Female Masculinity in Afghanistan

Afghanistan is one of the countries that implements strong patriarchic and masculine values in domestic and public spheres. The patriarchic structure was rooted in nomadic tribal societies' culture that privilege inheritance of the family through the male line only (Kabeer \& Khan, 2014). The subordination of Afghan women reflected in many ways, including men's control over women's labor power, reproduction, mobility, and economic resources (Schutte, 2013). The roles of Afghan women are very limited within the domestic sphere, and include activities such as giving birth and taking care of the children, cooking, cleaning and other household works. Purdah norms is a women's seclusion from the public sphere as this norm restrains women's mobility and activity outside or far from the house (Kabeer \& Khan, 2014). Women's position within marriage are under the husbands' patrilineal system of family in which Afghan women carry the responsibility to produce sons, maintain the family's honor, and later they gain some authority as mother-in-law (Riphenburg, 2003).

The use of language as a tool for gender subordination also occurs in Afghanistan. The notions of "honor" and "shame" used and embedded within the description of gender power relations between Afghan men and women (Schutte, 2013). Men believed to bring honor to the family, while Afghan women seen as the source of shame for the family. Therefore, sets of rules that restrict women's mobility outside the domestic sphere created in order to prevent the women from bringing shame in public. Schutte (2013) interviewed some Afghan women in Kabul, the capital city of Afghanistan, and the result of the research is that Purdah norms not only restrict the mobility of Afghan women, but also restrict their access to education. It has believed that if girls go to school, they will diminish the family honor and gain a bad reputation in society. 
So many privileges given to the men in Afghanistan that strengthen their position and place them at the top of the gender hierarchy. Men in Afghanistan have wider access to economic resources, mobility, and decision-making positions in the family structure. It is a tradition in many families to prefer the birth of sons to continue family line; the mother blamed if she gives birth to a girl (RFERL, 2012). A son or multiple male children are believed bring and protect the honor of the family, and become the economic support for (Kabeer \& Khan, 2014).

Afghanistan's preference for sons roots from the agricultural tradition in this country. Sons typically capable for the physical labor required to support their families. They built homes, looked after the sheeps and cattle, and did the farming. Boys could travel independently and work outside the home. When the sons married, they would bring their wives into the family, which mean bigger family to sustain the generation from the paternal line. Thus, sons contributed to the welfare of a family in a tangible ways. Daughters, on the other hand, would leave the family once they married and became part of their husbands' families (Hashimi, 2015).

Bacha Posh emerged as a response to the phenomenon of the strong preference of sons over daughters in Afghanistan. Bacha Posh means "girls dressed as boys", a secret underground of girls whose parents treat one of their daughters as a son (Bachaposh, 2014). Instead of wearing a veil and female dress, the girl will get a short haircut and a pair of pants, and she presented to the society as one of the boys. Parents allowed to changing their female child into a bacha posh by cutting her hair and dressing her in boy's clothing. The girl also given a boy's name. Some families start the conversion of their daughter's gender performance at birth, while others start once the girl has reached school age. Commonly the girls will live and perform as boys wholly and completely, both within and outside of the home (Hashimi, 2015). This is an old tradition before Islam took hold in 
the country, where society seen a girl as burden; parents cross-dress one of their daughters to look like a boy to preserve the family's honor (Lebrun, 2013; The Guardian, 2014).

There are many reasons for the family in Afghanistan to change their daughters' gender performance into boys, including economic factor social pressure to have sons in order to continue the family heirs, and in some cases, a superstition that doing so can lead for parents to give birth a male child in the future (Nordberg, 2010). The transformation showed a very practical advantage, since boy or the bacha posh can work outside the home for their families. Boys and bacha posh can sell goods on the street without any restriction as they were still dressed as girls. Some work as factory labors, bakers, carpet weavers, farmers, or brick makers also can be done by them to support family's economic condition (Hashimi, 2015).

Since the parents dress the girls in boy clothing and treat them as sons, tomboyism begins to develo The
Bacha Posh prefer to play with boyish toys and sports like soccer, and have more boy playmates than girls. Many Afghan families are raising their daughters as sons so the girls can help their families by working outside the house as girls typically forbidden to do (The Guardian, 2014). These "tomboy girls" can perform tasks that boys can do: they help their fathers' on farm jobs, herd and grass cattle, fix fences, escort their sisters and mothers, and other outdoor and physical works that girls do not do (Lebrun, 2013). Working in public sphere forbidden for girls in Afghanistan, but as Bacha Posh, girls have access to jobs outside the house. A bacha posh named Kamala works as a waiter in the teashop to support her family because she has six sisters and no brothers (Manoori \& Lebrun, 2014). Shop owners would not hire a girl, but it seems that a girl with masculine clothing and appearance is acceptable and the family's honor is preserved.

Raised as boys, most Bacha Posh would consider themselves boys and do not recognize any differences from 
their boy playmates. They enjoy the privileges of being boys. They can go to school and learn how to read and write, while ordinary girls not allowed to engaging in similar activities. Such girls experience freedom by becoming boys; many Bacha Posh expect to live in masculine for form the rest of their lives and resist the female identity (Manoori \& Lebrun, 2014; The Guardian, 2014). The gender segregation implemented in Afghanistan shapes the view of being a woman as limiting the freedom that every human should have.

Upon entering puberty, however, many Bacha Posh have to abandon their masculine attributes and shift from tomboy or female masculine identities into a feminine girl gender preference. From the age of twelve, the Bacha Posh who abandon the masculine attributes wear a veil and female dress, and learn how to behave as girls. Transition into the feminine identity means no more school, no more sports practices, no more friends, and no more life without constraints (Lebrun, 2013). Such girls forced to conform into feminine identity; in society, to disobey the biological-assigned gender means an offence to culture, religion and brings shame to the family. Bacha Posh is a very contradictive practice conducted by these Afghanistan families, since the families and society made the girls act as boys in the first place and then forced them to live as girls again.

The social pressures become reasons why many Bacha Posh give up their masculine identities and start to learn women's responsibilities at home. However, a few resist this transformation (Lebrun, 2013). Ukmina Manoori, as written in her memoirs as a Bacha Posh, shared that her family changed her name into masculine name (Hukomkhan) and treated her as a boy; she realized that there was a masculine identity inside her (Manoori \& Lebrun, 2014). When she was a little girl, she wanted to play with rifles and guns rather than with dolls. Thus at puberty, she refused to transform into a woman. She joined the Mujahedeen and served as a combatant during the war against the 
Soviet army (Manoori \& Lebrun, 2014). She had to hide her feminine identity by conforming to a masculine identity, covered and strapped her breasts, and lived as a man under the Taliban regime.

In Afghanistan where the patriarchic system upheld and the power of men and masculinity is glorified, gender identities and their position shaped through the lens of masculinity. Afghan society created children who "could almost be said to represent a third gender", as part of the desire for having sons to protect family's honor (The Guardian, 2014, para. 8). The patriarchy created female masculinity in Afghanistan, but it also limited the existence of female masculinity; the patriarchy excluded female masculinity from the power hierarchy of masculinity. The Bacha Posh do not have power to determine their gender preference and position in society. Once they have freedom within a masculine identity, but the future fixed and confirms for them that female masculinity should not be exist in adulthood or they will become the second-class of society by becoming women (Manoori \& Lebrun, 2014). Psychological disorders often happen to former Bacha Posh as many of them are still confused with their identity. They become sisters, wives, and mothers, but they find it difficult to adjust to their new identity as feminine women (The Guardian, 2014).

\section{CONCLUSION}

Culture and society make a significant contribution to gender identity by constructing and deconstructing gender identities. Female masculinity emerges as a resistance movement to challenge gender norms in society when women conform to a masculine identity. Adopting masculine appearance, behaviors and functions does not include female masculinity into a masculine category. Two considerations that explain female masculinity as being different more than traditional masculinity. First, female masculinity placed in an antagonistic position against 
masculinity and patriarchy. Female masculinity tries to deconstruct the biological-assigned gender norm that masculinity is not only the property of males or men. Their gender performativity could not categorized as feminine or masculine but may lead to a new gender category, known as transgender or transsexual. Second, with regard to power relations, female masculinity is often unrecognized. The individuals behave like men, but they do not have the power of men within a patriarchic system.

The Bacha Posh in Afghanistan are one of female masculinity's forms. Culture created these tomboy girls to take on the function of a boy in the family. They dress like boys, behave like boys and doing jobs those girls forbidden to do. However, when they reach puberty they often re-conform to feminine identity. Asymmetrical power relations could be understand from this case on how masculine and patriarchic systems reject the existence of the Bacha Posh when they reach adolescence. These tomboy girls do not have power to perform their gender preference, even though as Bacha Posh they used to have masculine freedoms. The exclusion of female masculinity is also part of the language used in the gender dichotomy and is used to describe female masculinity as "other" through the lens of masculinity.

\section{REFERENCE}

Bailey. M.J., Bechtold, K.T., and Berenbaum, S.A. (2002) "Who Are Tomboy and Why We Should Study Them?", Archives of Sexual Behavior. 31 (4), p 333-341 (Online). Available at: http://link.springer.com/article/10.1 023/A\%3A1016272209463

(Accessed: 5 May 2017).

Buttler, J. (1990) Gender Trouble. New York: Routledge.

Carr, C. L. (2007) "Where Have All the Tomboys Gone? Women's Accounts of Gender in Adolescence", Sex Roles, 56 (7-8), p 439-448 (Online).

Available at: http:/ /link.springer.com/article/10.1 007/s11199-007-9183-7 (Accessed: 8 May 2017).

Carr, C.L. (1998) Tomboy Resistance and Conformity: Agency in Social Psychological Gender Theory. Gender and Society, 12 (5), pp.528-553.

(Online). Available at: http://www.jstor.org/stable/190119 (Accessed 5 May 2017).

Cassano, M.C. and Zeman, J.L. (2010) "Parental Socialization of Sadness Regulation in Middle Childhood: The Role of Expectations and Gender". Developmental Psychology, 46(5), pp. 1214-1226 (Online). Available at: 
http://ovidstx.ovid.com (Accessed: 8 May 2017).

Claire, C.A. and Alderson, K.G. (2013) "Living Outside the Gender Binary: A Phenomenological Exploration into the Lived Experience of Female Masculinity". Canadian Journal of Counselling and Psychotherapy, 47(1), pp. 49-70 (Online). Available at: http:/ / cjcrcc.ucalgary.ca/cjc/index.php/rcc/arti cle/view/2657 (Accessed: 20 March 2018).

Connell, R.W. (2005) Masculinities 2nd Edition. Cambridge: Polity Press.

Cooper, B. (2002) 'Boys Don't Cry and Female Masculinity: Reclaiming a Life \& Dismantling the Politics of Normative Heterosexuality". Critical Studies in Media Communication, 19 (1), p 44-63 (Online). Available at: http://dx.doi.org/10.1080/07393180 216552 (Accessed: 30 March 2017).

Diamond, M., (2000) "Sex and gender: Same or different?". Feminism \& Psychology, 10 (1), p 46-54 (Online). Available at: http://ccsagepub.com/content/7/3/ 320.full.pdf + html (Accessed 5 May 2017).

Dragowski, E.A., Scharron-Del Rio, M.R., Sandigorsky, A.L. (2011) "Childhood Gender Identity...Disorder? Developmental, Cultural, and Diagnostic Concerns". Journal of Counseling \& Development, 89(3), 360366 (Online). Available at: http://onlinelibrary.wiley.com/doi/1 $0.1002 /$ j.15566678.2011.tb00100.x/epdf (Accessed: 8 May 2017).

Edley, N. and Wetherell, M. (1996) Masculinity, Power and Identity. In: M. Mac An Ghaill, ed. 1996. Understanding Masculinities. Buckingham: Open University Press.

Gardiner, J. K.. (2002) Introduction. In: J. K. Gardiner, ed. 2002. Masculinity
Studies and Feminist Theory: New

Directions. New York: Columbia University Press.

Halberstam, J. (1998) Female Masculinities. Durham N.C.: Duke University Press.

Halberstam, J. (2012) "Global Female Masculinities". Sexualities, 15(3/4), p 336- 354 (Online). Available at: http://sex.sagepub.com/content/15/ 3- 4/336.full.pdf + html (Accessed: 5 May 2017).

Hashimi, N. (2015) Afghanistan's Female Sons: The Tradition of Bacha Posh (Online), in: https://www.foreignaffairs.com/articl es/afghanistan/2015-0413/afghanistans- female-sons (Accessed: 20 March 2018).

Hooper, C. (2001) Manly States: Masculinities, International Relations, and Gender Politics. New York Chichester: Columbia University Press.

Kabeer, N. and Khan, A. (2014) "Cultural Values or Universal Rights? Women's Narratives of Compliance and Contestation in Urban Afghanistan". Feminist Economics, 20 (3), pp. 1-24 (Online). Available at: http://dx.doi.org/10.1080/13545701. 20 14.926558 (Accessed 8 May 2017).

Lebrun, S. (2013) Preface. In: Manoori, U. and Lebrun, S. I Am a Bacha Posh: My Life as $A$ Woman Living as A Man in Afghanistan. Translated from France by E. Chianchiano Jr. New York: Skyhorse Publishing.

Levitt, H. M., \& Hiestand, R. (2004) “A Quest for Authenticity: Contemporary Butch Gender". Sex Roles: A Journal of Research, 50(9-10), 605-622. (Online). Available at: http://link.springer.com/article/10.1 023/B\%3ASERS.0000027565.59109.8 0 (Accessed: 30 March 2017).

Manoori, U. and Lebrun, S. (2014) I Am a Bacha Posh: My Life as A Woman Living as A Man in Afghanistan. Translated 
from France by E. Chianchiano Jr. New York: Skyhorse Publishing.

Nguyen, A. (2008) Patriarchy, Power, and Female Masculinity. Journal of Homosexuality, 55 (4), pp. 665-683 (Online). Available at: http:/ /dx.doi.org/10.1080/00918360 802498625 (Accessed: 30 March 2017).

Nordberg, J. (2010) Afghan Boys Are Prized, So Girls Live the Part (Online).

Available at:

http://www.nytimes.com/2010/09/2 $1 /$ world/asia/21gender.html (Accessed: 20 March 2018).

RFERL (Radio Free Europe Radio Liberty). (2012) Baby Girls Seen as Mixed Blessing in Afghanistan (Online). Available at: http://www.rferl.org/content/baby_g irls_seen_as_mixed_blessing_in_afgha nistan/24476659.html (Accessed: 8 May 2017).

Riphenburg, C.J. (2003) "Gender Relations and Development in a Weak State: The Rebuilding of Afghanistan". Central Asian Survey, 22 (2), pp. 187207 (Online). Available at: http://dx.doi.org/10.1080/02634930 32000157726 (Accessed: 8 May 2017).
Schütte, S. (2014) "Living with Patriarchy and Poverty: Women's Agency and the Spatialities of Gender Relations in Afghanistan". Gender, Place \& Culture: A Journal of Feminist Geography, 21 (9), pp. 1176-1192 (Online). Available at: http://dx.doi.org/10.1080/0966369X .2013 .832661 (Accessed: 5 May 2017).

The Guardian. (2014) The Afghan Girls Raised as Boys (Online). Available at: http://www.theguardian.com/lifeand styl e/2014/sep/22/girls-boysafghanistan- daughters-raised-as-sonspuberty-bacha- posh (Accessed: 20 march 2017).

What is Bacha Posh?. (2014) (Online).

Available at: http://bachaposh.com/bacha-posh2/ (Accessed: 5 May 2017).

Wickman, J. (2003) "Masculinity and Female Bodies". NORA - Nordic Journal of Feminist and Gender Research, 11(1), pp. 40-54 (Online). Available at: http:/ /dx.doi.org/10.1080/08038740 307272 (Accessed: 5 May 2017).

Wiegman, R. (2002) Unmaking: Men and Masculinity in Feminist Theory. In: J. K. Gardiner, ed. 2002. Masculinity Studies and Feminist Theory: New Directions. New York: Columbia University Press. 